\title{
Communication/Comunicação
}

\section{Simultaneous circulation of all four dengue serotypes in Manaus, State of Amazonas, Brazil in 2011}

\author{
Circulação simultânea dos quatro sorotipos do vírus dengue em Manaus, Estado do Amazonas, \\ Brasil em 2011
}

\begin{abstract}
Michele de Souza Bastos ${ }^{1,2}$, Regina Maria Pinto de Figueiredo ${ }^{1}$, Rajendranath Ramasawmy ${ }^{1,3}$, Evaulino Itapirema $^{1}$, João Bosco Lima Gimaque ${ }^{1,2}$, Lucilaide Oliveira Santos ${ }^{1,2}$, Luiz Tadeu Moraes Figueiredo ${ }^{4}$ and Maria Paula Gomes Mourão ${ }^{1,2,3}$
\end{abstract}

\begin{abstract}
Introduction: Manaus, the capital city of the State of Amazon with nearly 2 million inhabitants, is located in the middle of the Amazon rain forest and has suffered dengue outbreaks since 1998. Methods: In this study, blood samples were investigated using reverse transcriptase-polymerase chain reaction (RT-PCR), aimed at identifying dengue virus serotypes. Results: Acute phase sera from 432 patients were tested for the presence of dengue virus. Out of the 432 patients, 137 (31.3\%) were found to be positive. All the four dengue virus serotypes were observed. Conclusions: The simultaneous circulation of the four dengue serotypes is described for the first time in Manaus and in Brazil.
\end{abstract}

Keywords: Dengue. Reverse transcriptase-polymerase chain reaction. Serotypes.

\section{RESUMO}

Introdução: Manaus, capital do Estado do Amazonas, com quase 2 milhões de habitantes, está localizada no meio da floresta Amazônica e vem sofrendo surtos de dengue desde 1998. Métodos: Neste estudo, amostras de sangue foram investigadas pela Transcriptase reversa-reação em cadeia da polimerase (RT-PCR), visando identificar os sorotipos de vírus da dengue. Resultados: Soros de fase aguda de 432 pacientes foram testados para a presença do vírus da dengue. Destes, 137 (31,3\%) foram considerados positivos. Todos os quatro sorotipos do vírus da dengue foram observados. Conclusões: A circulação simultânea dos quatro sorotipos da dengue é descrita pela primeira vez em Manaus e no Brasil.

Palavras-chaves: Dengue. Transcriptase reversa-reação em cadeia da polimerase. Sorotipos.

Dengue fever (DF) is the most prevalent arboviral disease worldwide. Around 2.5 billion people, especially those living in the tropical and subtropical areas, are at risk of infection with dengue virus ${ }^{1}$. Dengue viruses (DENVs) belong to the genus Flavivirus, family Flaviviridae. They are single-stranded, positive-sense, RNA viruses grouped into four antigenically related but distinct serotypes named DENV-1, 2, 3, and 42 .

1. Laboratório de Virologia, Fundação de Medicina Tropical Dr. Heitor Vieira Dourado, Manaus, AM. 2. Programa de Pós-Graduação em Medicina Tropical, Universidade do Estado do Amazonas, Manaus, AM. 3. Curso de Medicina, Universidade Nilton Lins, Manaus, AM. 4. Centro de Pesquisa em Virologia, Faculdade de Medicina de Ribeirão Preto, Ribeirão Preto, SP.

Address to: Dra Maria Paula Gomes Mourão. Laboratório de Virologia/FMT-HVD. Av. Pedro Teixeira 25, 69040-000 Manaus, AM, Brasil.

Phone: 5592 2127-3447

e-mail: mariapaula.mourao@gmail.com

Received in 11/05/2011

Accepted in 29/07/2011
The first epidemic of dengue fever in Brazil, with isolation of the virus, occurred in 1981, in the State of Roraima, when DENV-1 and DENV-4 were identified ${ }^{3}$. In 1986, DENV-1 was identified in the State of Rio de Janeiro ${ }^{4}$ and subsequently disseminated to other states of Brazil.

Manaus, the capital city of the Amazonas State with almost 2 million inhabitants, is located in the middle of the Amazon rain forest and has suffered dengue outbreaks since 1998, when a huge outbreak of dengue fever happened for the first time. Approximately 20,000 cases, caused by serotype 1 , were reported ${ }^{5}$. At the end of the same year, dengue serotype 2 was detected for the first time in this city. In 2001, DENV-2 produced the second large outbreak with 30,000 reported cases, including 60 dengue hemorrhagic fever cases ${ }^{6}$. On October of 2002, dengue serotype 3 was detected in Manaus. Since then, during rainy seasons, it has suffered outbreaks with increasing number of severe dengue cases, mostly in children ${ }^{7}$. Lately, on January of 2008, in Manaus, dengue serotype 4 was detected for the first time in Brazil after a lapse of 26 years ${ }^{8}$. Since then, all dengue serotypes have occurred in turns in Manaus. However, following an upward trend of dengue in Brazil, in the first months of 2011, a new dengue fever outbreak started in Manaus with almost 40,000 cases, affecting residents from all regions in the city and causing disease of distinct severities.

A total of 432 blood samples were collected from patients with $<7$ days of fever presenting to the outpatient clinic and the emergency department of the Fundação de Medicina Tropical Dr. Heitor Vieira Dourado, a tertiary and public health care center, reference for tropical and infectious diseases, located in the City of Manaus, from January to April of 2011. As these were diagnostic samples received during the outbreak, no prior ethical clearance was required.

Viral RNA was extracted from serum samples using the QIAamp Viral RNA mini kit (Qiagen, Germany) as per manufacturers' instructions. Extracted RNA was stored at $-70^{\circ} \mathrm{C}$ or used for RT-PCR immediately. The RNA was used for dengue virus detection and typing in a semi-nested multiplex reverse transcription-PCR protocol as described by Lanciotti et al. ${ }^{9}$ RNA extracts of the positive samples were also re-analyzed in a singleplex PCR reaction using the same individual type-specific primers.

Of the 432 patients with DF, 137 ( $\sim 31 \%)$ were found positive for dengue virus by RT-PCR. One hundred and twenty-one had monoinfection by one single serotype, while 16 had co-infections by two serotypes of DENV. Of the 121 patients with monoinfection, $51,31,22$, and 17 had serotypes DENV-2, DENV-4, DENV-3, and 
DENV-1, respectively. DENV-2 (42\%) was predominant, followed by DENV-4 (25.6\%). The presence of co-infections was $13 \%$ (16 out of 137 patients positive for dengue virus). Of these 16 patients with DF co-infections by at least two serotypes, DENV-4 and DENV-3 were observed in $37.5 \%$ (6/16). Other combinations of co-infections were: DENV-1 and DENV-4 in 31\% (5/16); DENV-1 and DENV-2 in $18.7 \%(3 / 16)$; and DENV-2 and DENV-3 in $12.5 \%$ $(2 / 16)$, respectively. So far, there are no data enough to support if coinfections are more severe than monoinfections. Further studies are needed to address the potential severity in co-infections with different dengue serotypes or even with dengue and other arboviruses.

The simultaneous circulation of all four serotypes in Manaus is a clear evidence of dengue hyperendemicity, and it will, probably, result in increasing morbidity, severe forms of dengue disease, and fatalities. Therefore, this situation may increase the tendency, as previously detected, for predominance of severe forms of dengue in children.

Further studies are necessary to understand the virulence as well as spreading potential and magnitude of participation of each dengue serotype and its combinations in this outbreak.

\section{ACKNOWLEDGMENTS}

We thank the board of directors and members of the Clinical Department of the Fundação de Medicina Tropical Dr. Heitor Vieira Dourado (FMT-HVD), as well as Dr. Milton Moraes (senior visiting researcher), for their support and contribution to this work.

\section{CONFLICT OF INTEREST}

The authors declare that there is no conflict of interest.

\section{FINANCIAL SUPPORT}

This research was supported by the Fundação de Amparo à Pesquisa do Estado do Amazonas (FAPEAM) through grant \#887/2010.

\section{REFERENCES}

1. World Health Organization. Dengue and dengue hemorrhagic fever. [Cited 2011 may 4]. Available from: http://www.who.int/mediacentre/factsheets/fs117/en/.

2. Gubler DJ. Dengue and dengue haemorrhagic fever. Clin Microbiol Rev 1998;11:480 496

3. Osanai CH, Travassos da Rosa APA, Tang AT, Amaral RS, Passos ADC, Tauil PL. Surto de dengue em Boa Vista Roraima. RevInst Med Trop São Paulo 1983; 25:53-54.

4. Nogueira RMR, Schatzmayr HG, Miagostovich MP, Farias MF, Farias Filho FC. Mem Inst Oswaldo Cruz 1988; 83:219-225.

5. Figueiredo RM, Thatcher BD, Lima ML, Almeida TC, Alecrim WD, Guerra MV. Exanthematous diseases and the first epidemic of dengue to occur in Manaus, Amazonas, State, Brazil, during 1998-1999. Rev Soc Bras Med Trop 2004; 37:476-479.

6. Figueiredo RM, Bastos MS, Lima ML, Almeida TC, Alecrim WD. Dinâmica da sorologia e isolamento viral na epidemia de dengue em Manaus (1998-2001). Rev Soc Bras Med Trop 2002; 35 (supl 1): 94.

7. Rocha LA, Tauil PL. Dengue em criança: aspectos clínicos e epidemiológicos, Manaus, Estado do Amazonas, no período de 2006 e 2007. Rev Soc Bras Med Trop 2009; 42:18-22.

8. Figueiredo RMP, Naveca FG, Bastos MS, Melo MN, Viana SS, Mourão MPG, et al. Dengue Virus Type 4, Manaus, Brazil. Emerg Infect Dis 2008 14:4:667-669.

9. Lanciotti RS, Calisher CH, Gubler DJ, Chang GJ, Vorndam AV. Rapid detection and typing of dengue viruses from clinical samples by using reverse transcriptasepolymerase chain reaction. J Clin Microbiol 1992; 30:545-551. 